\title{
VALDEZ GLACIER ICE-DAMMED LAKE: JUNE 2017 GLACIAL LAKE OUTBURST FLOOD
}

Gabriel J. Wolken and Katreen Wikstrom Jones

Preliminary Interpretive Report 2017-4

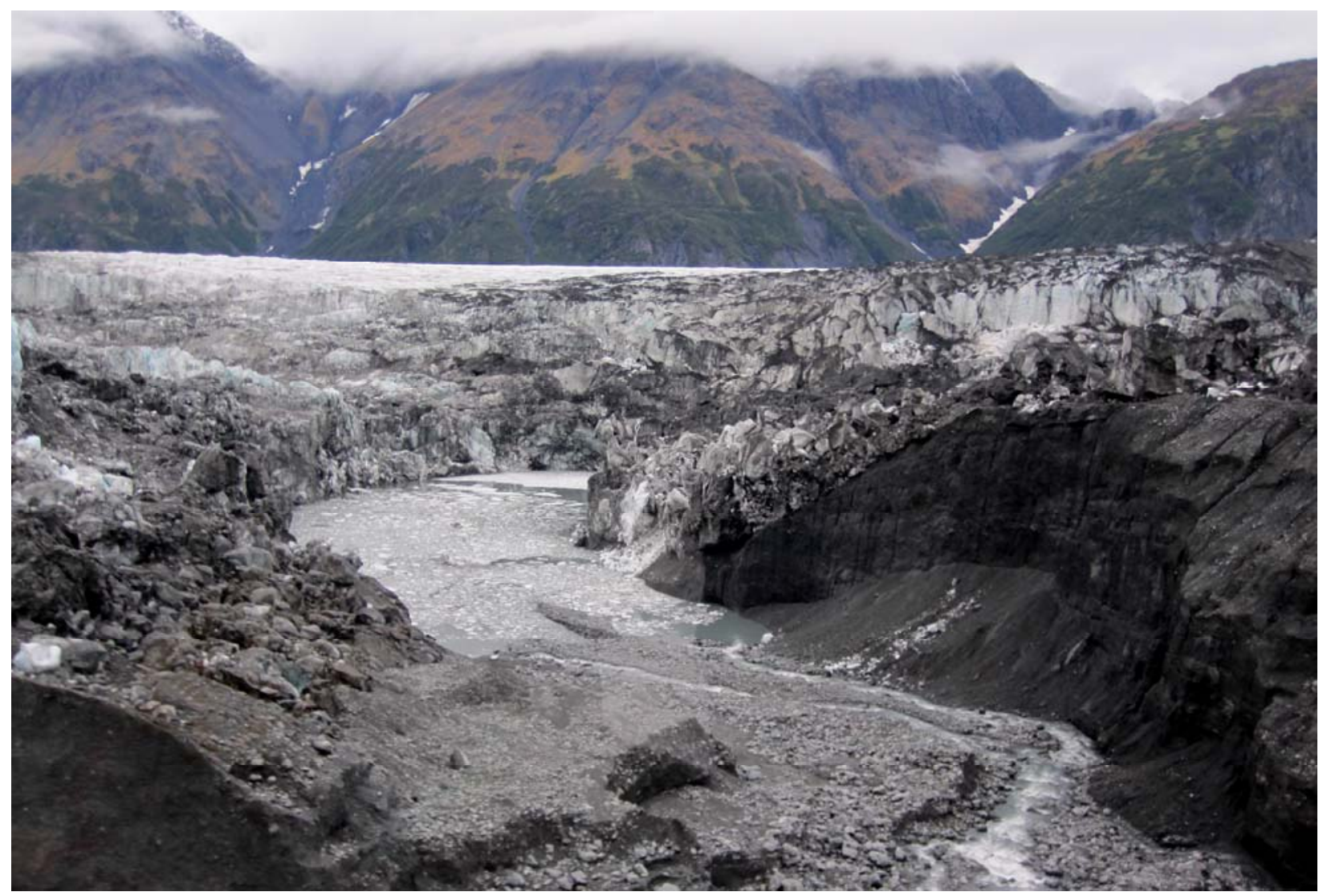

Valdez Glacier. Photo by Gabriel Wolken.

August 2017

State of Alaska

Department of Natural Resources

Division of Geological \& Geophysical Surveys

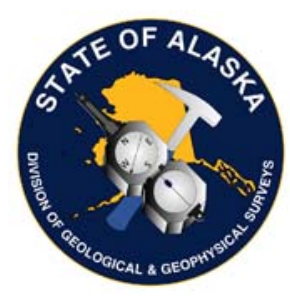





\section{VALDEZ GLACIER ICE-DAMMED LAKE: \\ JUNE 2017 GLACIAL LAKE OUTBURST FLOOD}

Gabriel J. Wolken and Katreen Wikstrom Jones

Preliminary Interpretive Report 2017-4

State of Alaska

Department of Natural Resources

Division of Geological \& Geophysical Surveys 


\section{STATE OF ALASKA \\ Bill Walker, Governor}

DEPARTMENT OF NATURAL RESOURCES

Andrew T. Mack, Commissioner

DIVISION OF GEOLOGICAL \& GEOPHYSICAL SURVEYS

Steve Masterman, State Geologist \& Director

Publications produced by the Division of Geological \& Geophysical Surveys are available for free download from the DGGS website (dggs.alaska.gov). Publications on hard-copy or digital media can be examined or purchased in the Fairbanks office:

\section{Alaska Division of Geological \& Geophysical Surveys (DGGS)}

3354 College Road | Fairbanks, Alaska 99709-3707

Phone: 907.451 .5010 | Fax 907.451.5050

dggspubs@alaska.gov | dggs.alaska.gov

\section{DGGS publications are also available at:}

Alaska State Library, Historical

Collections \& Talking Book Center

395 Whittier Street

Juneau, Alaska 99801

Alaska Resource Library and

Information Services (ARLIS)

3150 C Street, Suite 100

Anchorage, Alaska 99503

\section{Suggested citation:}

Wolken, G.J., and Wikstrom Jones, Katreen, 2017, Valdez Glacier ice-dammed lake: June 2017 glacial lake outburst flood: Alaska Division of Geological \& Geophysical Surveys Preliminary Interpretive Report 2017-4, 5p.

\section{http://doi.org/10.14509/29743}
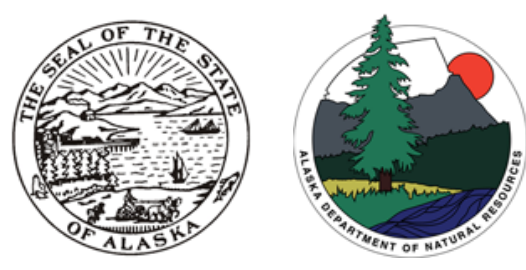


\section{VALDEZ GLACIER ICE-DAMMED LAKE: JUNE 2017 GLACIAL LAKE OUTBURST FLOOD}

Gabriel J. Wolken' and Katreen Wikstrom Jones ${ }^{1}$

Alaska is host to a large number of glacial lakes, many of which can be a serious threat to downstream communities and infrastructure if their natural dams are breached and outburst floods occur (Post and Mayo, 1971). Glacial lake outburst floods (GLOFs) result from the rapid release of water from a glacial lake due to sudden failure of an ice- or moraine-dam or water overtopping the dam as a result of displacement waves, commonly caused by mass wasting of nearby unstable slopes.

The Valdez Glacier ice-dammed lake (IDL) is located $7.2 \mathrm{~km}$ ( $4.5 \mathrm{mi})$ up-glacier from the current terminus position at an elevation of approximately $280 \mathrm{~m}(722 \mathrm{ft})$ above sea level, adjacent to the east margin of the glacier (fig. 1). The basin in which the lake forms was previously occupied by the unnamed tributary glacier to the east, and is repeatedly filled from glacier, snow, and rain runoff. The Valdez

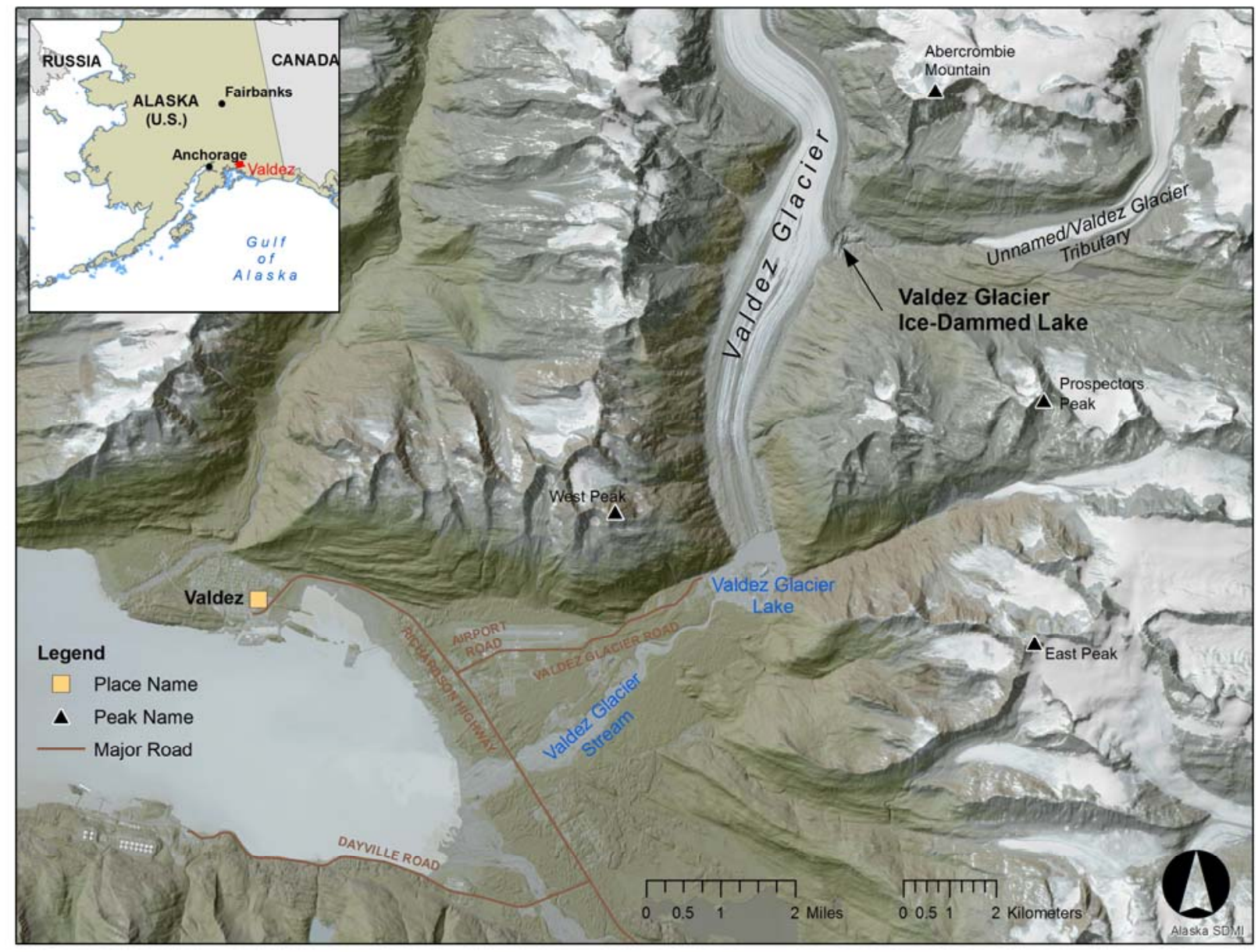

Figure 1. Location of Valdez Glacier ice-dammed lake (Source: DGGS, 2017).

\footnotetext{
${ }^{1}$ Alaska Division of Geological \& Geophysical Surveys, Climate \& Cryosphere Hazards Program, 3354 College Road, Fairbanks, AK 99709-3707
} 
Glacier IDL produces annual to bi-annual outburst floods of varying magnitude. One outburst event regularly occurs in June following spring snowmelt, and a second outburst event typically occurs in September-October in association with heavy precipitation (rain) from fall storms.

The exact dynamics of each GLOF are currently unknown, but the triggering mechanism is likely related to increasing water pressure as the lake volume increases, and sudden expansion of englacial and subglacial conduits of Valdez Glacier, which enable water to be efficiently transported down-glacier. The water exits Valdez Glacier and enters Valdez Glacier Lake subaqueously, causing a rapid increase in the proglacial lake level that translates into localized flooding and an increase in the discharge of Valdez Glacier Stream (fig. 1).

The volume of the IDL prior to each outburst event varies. We estimate IDL volumes by identifying water level position with respect to reference markers on telemetered images from an automatic remote viewer camera. Water level positions are converted to heights and lake volume is calculated using a recent highresolution digital surface model (DSM) of the low lake level IDL basin. The IDL volume prior to June 13, 2015, produced the largest GLOF in the observable record (observed on June 11 with a remote view camera), but the outburst event in June 2016 was probably larger, or the water release and conveyance was faster, given the magnitude of flooding of Valdez Glacier Stream (no camera available). In 2017 we observed the highest IDL level on June 26 (fig. 2) followed by steady release of water from the IDL-i.e., a slower outburst event than previous years.

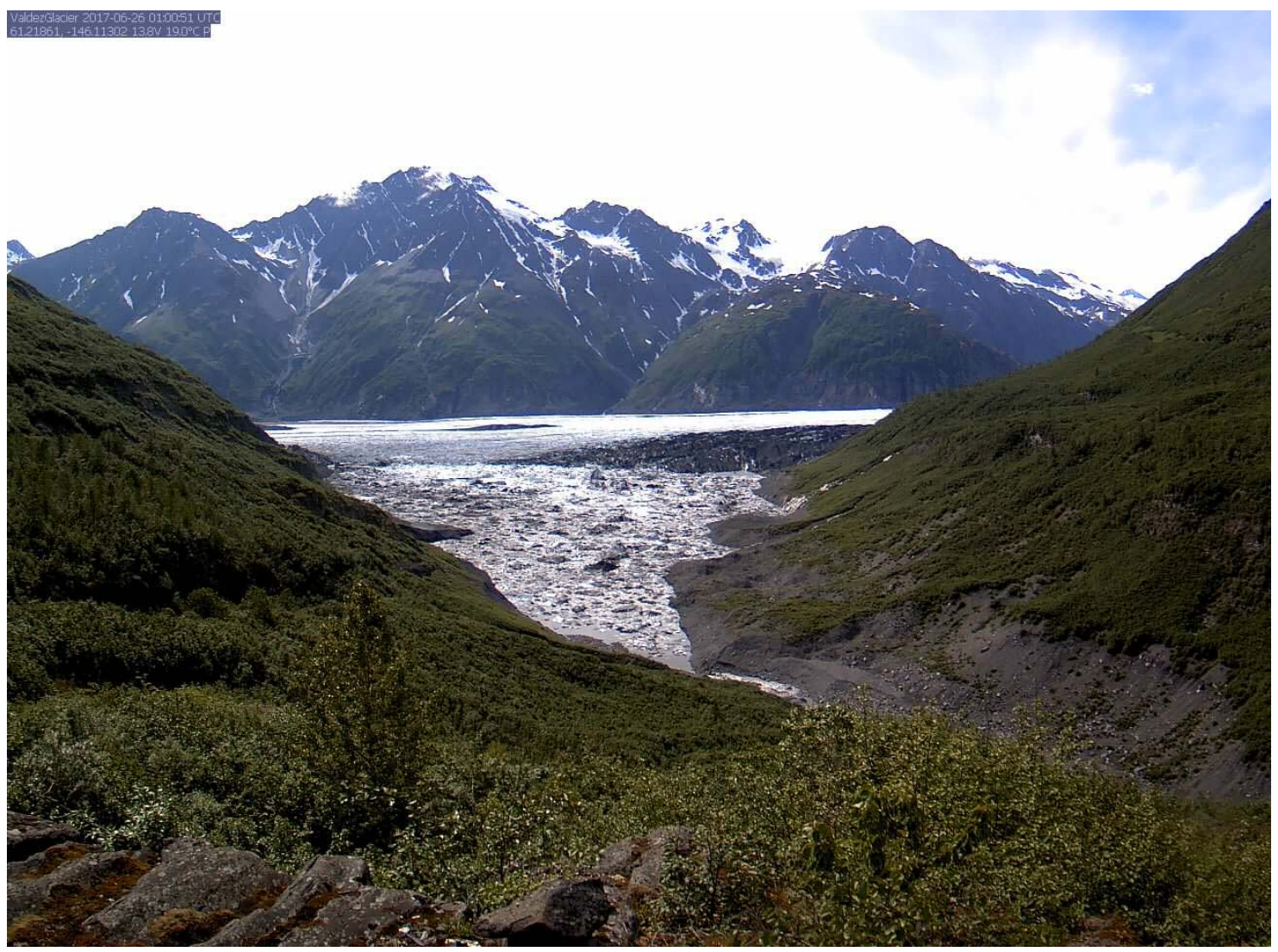

Figure 2. Water level of Valdez Glacier Ice-Dammed Lake before outburst, observed on 06/26/2017. 
Based on the highest lake level on June 26, 2017, we estimate the lake volume was $18,000,000 \mathrm{~m}^{3}$ $\left(636,000,000 \mathrm{ft}^{3}\right.$, or the equivalent of 7,200 Olympic swimming pools) compared to $32,500,000 \mathrm{~m}^{3}$ $\left(1,148,000,000 \mathrm{ft}^{3}\right)$ prior to the June 2015 event (fig. 3). As a result of the multi-day outburst, the water level in the iceberg-filled IDL had noticeably reduced by June 28 (fig. 4) and appeared empty by June 30 (fig. 5). These observations closely correspond to changes in water level observed at a newly-installed USGS gage in Valdez Glacier Lake, where water level increased $\sim 0.3 \mathrm{~m} / \mathrm{d}(1 \mathrm{ft} / \mathrm{d})$ from June 25 through June 28 (fig. 6). Due to the slower than normal outburst in June 2017, flooding of Valdez Glacier Lake and Valdez Glacier Stream was minimal, with little damage to property and infrastructure reported.

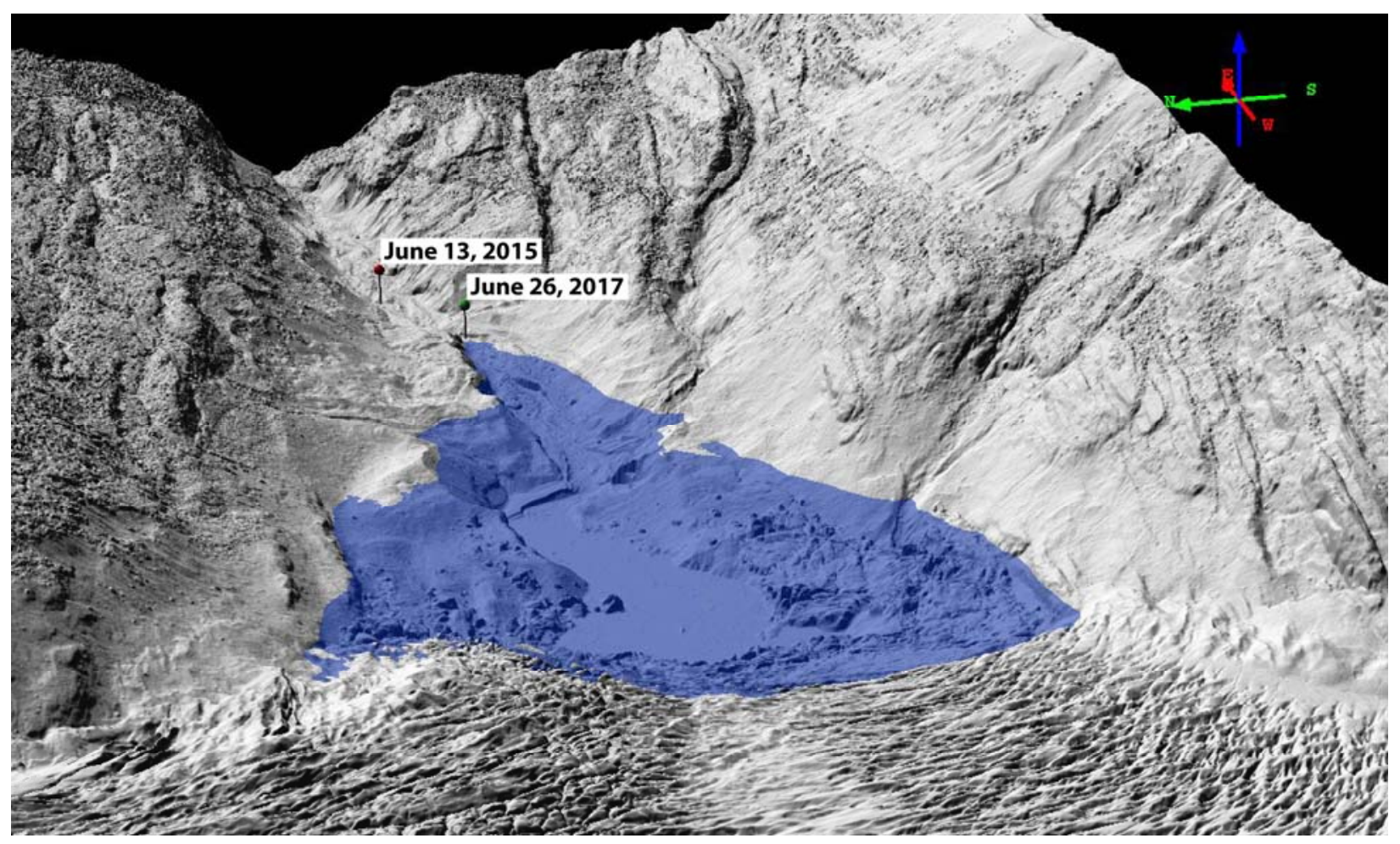

Figure 3. Maximum extent of the Valdez Glacier IDL (shown in purple) from which volume estimates are calculated prior to the June 2017 outburst. Volume estimates are based on the 06/26/2017 water level and the 10/15/2014 low lake level reference DSM. Note the location of the June 13, 2015 lake level (Source: DGGS, 2017). 




Figure 4. Post-outburst water level in the Valdez Glacier IDL as observed on 06/28/2017.

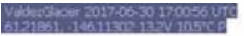

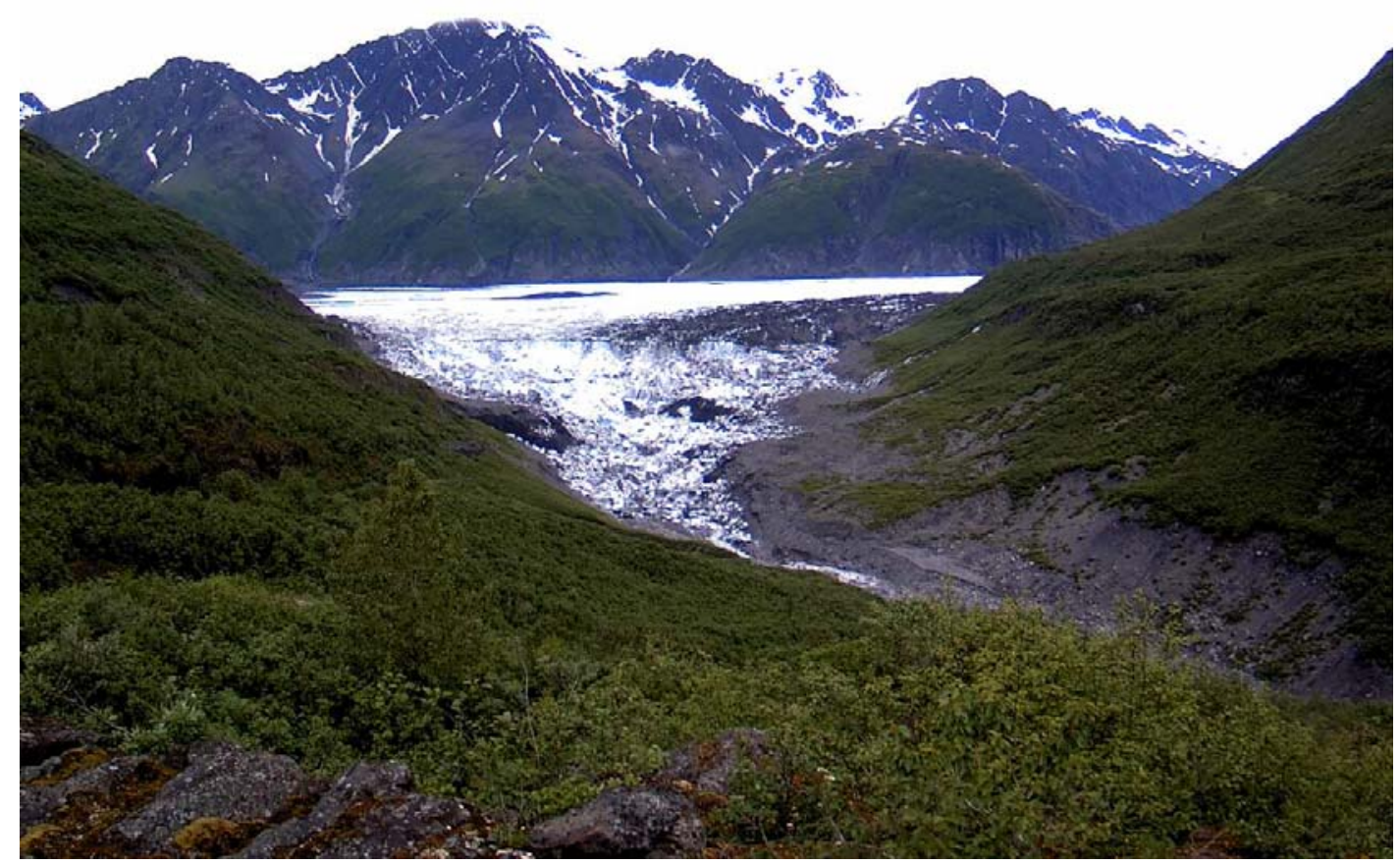

Figure 5. Post-outburst water level in the Valdez Glacier IDL as observed on 06/30/2017. 
USGS 15227090 yaLDEZ GLACIER R AT YALDEZ GLACIER LK NR YALDEZ AK

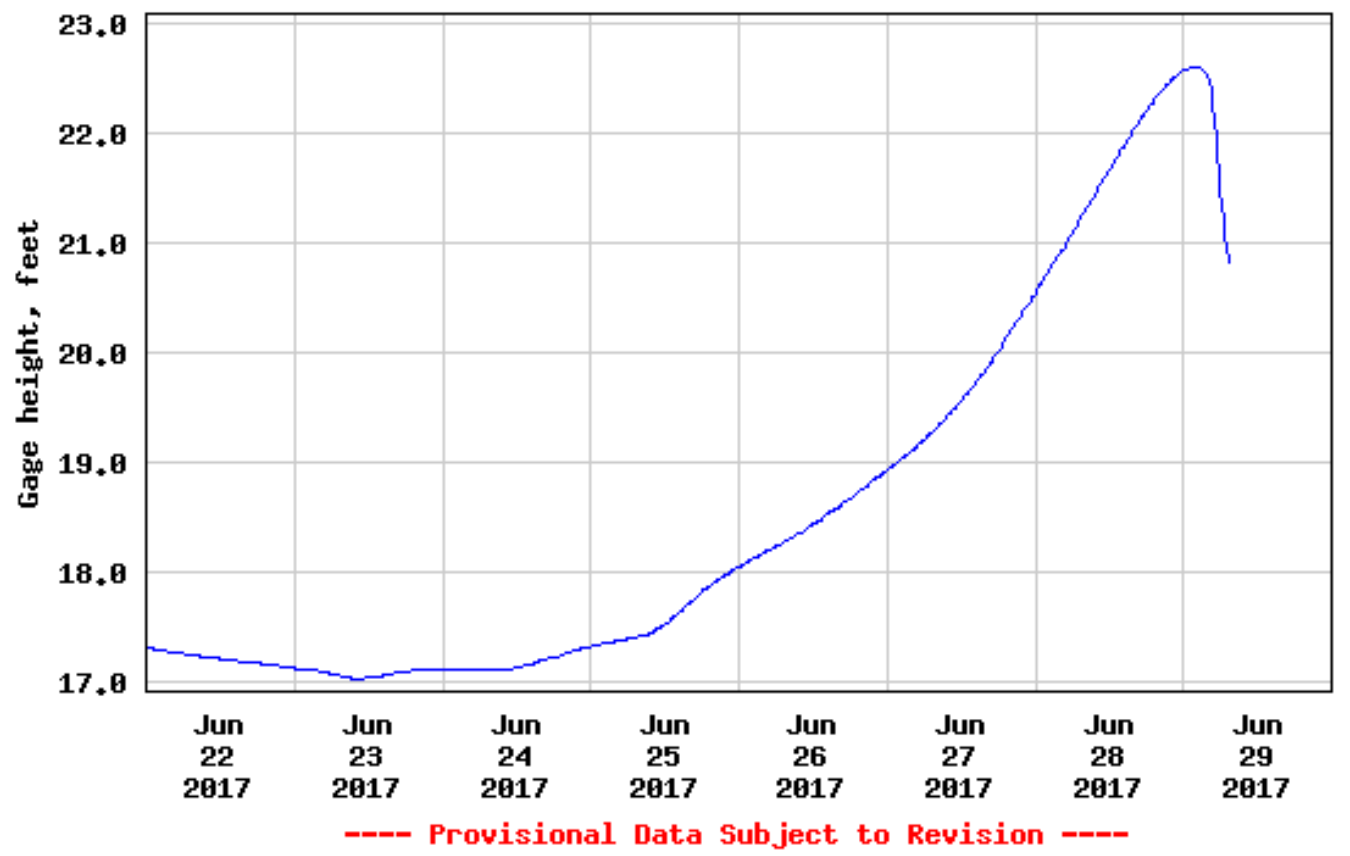

Figure 6. Gage height (feet) in Valdez Glacier Lake on June 22-29, 2017. Source:

https://waterdata.usgs.gov/ak/nwis/uv/?site no=15227090\&PARAmeter cd=00065,00060

\section{Acknowledgments}

This work was supported by the City of Valdez, the State of Alaska through Capital Improvement Project funding, and the Alaska Climate Science Center, University of Alaska Fairbanks.

\section{References Cited}

Post, Austin, and Mayo, L.R., 1971, Glacier dammed lakes and outburst floods in Alaska: U.S. Geological Survey Hydrologic Investigations Atlas 455, 10 p., 3 sheets, scale 1:1,000,000. 